\title{
Incidence of banana leaf roller and diversity of it is parasitoids in Central Sulawesi, Indonesia
}

\author{
FLORA PASARU, MOHAMMAD YUNUS, MOH. HIBBAN TOANA, NUR EDY, ALAM ANSHARY, \\ SHAHABUDDIN SALEH ${ }^{\vee}$ \\ Department of Plant Pests and Diseases, Faculty of Agriculture, Universitas Tadulako. Jl. Soekarno Hatta Km. 9, Palu 94118, Central Sulawesi, \\ Indonesia. Tel.: +62-451-422611, Fax.: +62-451-429738, `email: shahabsaleh@ gmail.com
}

Manuscript received: 5 August 2021. Revision accepted: 24 October 2021.

\begin{abstract}
Pasaru F, Yunus M, Toana MH, Edy N, Anshary A, Saleh S. 2021. Incidence of banana leaf roller and diversity of it is parasitoids in Central Sulawesi, Indonesia. Biodiversitas 22: 5023-5029. Incidence of banana leaf roller and diversity of it is parasitoids in Central Sulawesi, Indonesia. Indonesia is still facing banana losses due to the leaf roller (Erionota thrax). Fortunately, it has several natural enemies potentially to control them. Therefore, a survey was done to measure the incidence of banana leaf roller (BLR) at different altitudes and banana cultivars as well as the diversity and parasitism of its parasitoids. The pra-imago stages of BLR were collected at different altitudes and banana cultivars in Central Sulawesi, Indonesia, and transported to the laboratory for rearing and parasitism observation. The study revealed that the incidence of $E$. thrax in the surveyed locations varied from $28.6 \%$ to $85.8 \%$, whereas the parasitism level of the BLR parasitoids was 0.0 to $22.1 \%$. Incidence of $E$. thrax tended to be higher at a higher altitude while Kepok cultivar seemed to be less prone to BLR infestation compared with Raja and Mas cultivars. A total of nine parasitoids of BLR were recorded. They were Agiommatus sumatraensis, Pediobius erionotae, Ooencyrtus pallidipes, Brachymeria lasus, Brachymeria thracis, Cotesia erionatae, Xanthopimpla gampsura, Casinaria sp, and Palexorista solennis. Among them, B. lasus was the most abundant, widely distributed, and had the highest parasitism rate. Our study figured out that BLR infestation is a major problem in Central Sulawesi. Nevertheless, the presence of parasitoids recorded in this study may potentially be used as the biological control.
\end{abstract}

Keywords: Banana skipper, BLR parasitoid, parasitism

\section{INTRODUCTION}

Bananas have mostly been planted in tropical countries. In Indonesia, it is developed by a big plantation company and as a garden plant. Banana occupies first place among other fruits in terms of distribution, area of planting, production, and as the most desirable fruits (Suyamto et al. 2005). However, there are some limiting production factors of the banana, including pest infestation. One of the main pests of bananas is the banana skipper, also known as the banana leaf roller (BLR). There are two species of skippers of the genus Erionota Mabille (Lepidoptera: Hesperiidae) that feed on banana leaves recorded in Southeast and South Asia namely E. thrax L. and E. torus Evans (Cock 2015; Irulandi et al. 2018). The imago of these two species can usually be distinguished by the wing variations where the forewing of $E$. thrax has a straight outer margin and acute apex. In contrast, the forewing of E. torus is more convex in the outer margin and rounded apex (Poorani et al. 2020). The taxonomy, distribution, food plants, and natural enemies of the BLR have been decisively reviewed by Cock (2015).

BLR is a slightly important pest in Asia. However, during the last two decades, the outbreak of BLR expanded and caused serious defoliators (Cock 2015; Poorani et al. 2020). The feeding activity of the BLR larva causes considerable damage to the banana's foliage by rolling the leaf while feeding on it. Although banana plants can tolerate up to $20 \%$ defoliation, a heavy infestation can damage the whole banana leaf, leaving only the midrib intact. At $50 \%$, defoliation by BLR larva will cause about $28 \%$ of yield losses (Cock 2015). The lower yields of infested banana by BLR is due to the delayed fruit maturity and reduced the bunch size (Abdul and Gosh 2020).

The infestation area of $E$. thrax in Indonesia tends to increase. In Central Sulawesi, a new infestation area of this banana pest ranged from 35 to 108 ha from 2014 to 2018 (Ditlin 2019). Several studies in Indonesia reported the parasitic wasps (Hymenoptera) and flies (Diptera) that potentially control the banana skipper (e.g., Hasyim et al. 1994; Hasyim et al. 1999; Erniwati and Ubaidillah 2011; Rahmawati et al. 2018). Nevertheless, most of those studies were conducted in Sumatra and Java Island. Additionally, the environmental factors, including weather, altitudes, natural enemies, and the banana cultivars influencing the population and infestation of BLR (Sharanabasappa et al. 2016; Irulandi et al. 2018).

Therefore, information about the infestation of BLR, their parasitoid at different altitudes and banana cultivars in Central Sulawesi known as one of the biodiversity hotspots in the Wallacea region, is urgent to be discovered. This study provides baseline data of BLR incidence on different banana cultivars in this region as well as the diversity and parasitism of the BLR potentially use as biological control agents. 


\section{MATERIALS AND METHODS}

\section{Study area}

The research was carried out in the banana plantation in four villages of three districts in Central Sulawesi, Indonesia, i.e., Parigi Moutong, Sigi and Poso districts. The map of study sites is plotted as coordinate locations of research sampling by using Tableau free edition (Figure 1). The majority of bananas are grown in the home garden. They are cultivated as a sole crop, border crop, or intercrop in coconut and cacao plantations and several other crops.

The study sites in each district were selected purposively based on environmental factors, particularly elevation, and cultivar of bananas (Table 1). Altitudes, win speed, temperature, and moisture were measured at one meter from the ground by using a digital environment meter (MASTECH MS 6300, Mastech, Indonesia), while rainfall data was taken from the Meteorology, Climatology, and Geophysical Agency of Central Sulawesi.

\section{Insect sampling and identification}

The incidence of BLR was observed on each study site from April to August 2019. Eighty trees of the banana plants were observed at each study site. Plant with at least one leaf roll in a leaf was considered infested. For identification and parasitism observation, three eggs group and twenty leaf rolls per site were collected randomly and reared at the Plant Pest Laboratory, Faculty of Agriculture, Tadulako University. The BLR and parasitoids were identified using several determination keys (Goulet and Huber 1993; Zhang et al. 2005; O'hara et al. 2009; Erniwati and Ubaidillah 2011). Species identification was then verified by the taxonomist of Museum Zoologium Bogorienze (MZB) of the National Research and Innovation Agency (BRIN). The scientific name of parasitoids encountered was checked at the database available at the Global Biodiversity Information Facility (https://www.gbif.org/).

\section{Data analysis}

Descriptive and inferential statistics were used for the data analysis. The level of incidence or infestation of BLR was calculated as:

Percent incidence $(\mathrm{PI})=\frac{\text { Number of infested plants }}{\text { Total plants observed }} \times 100 \%$

Categorization of pest incidence was modified from Pratiwi et al. (2020) as follow: low (<25\%), medium ( $>25-$ $50 \%)$, quite high $(>50-75 \%)$, and heavy (>75\%) levels. Parasitism level was calculated as:

Percent parasitism $=\frac{\text { Number of parasitized of eggs or larvae }}{\text { Number of eggs or larvae observed }} \times 100 \%$

Data were checked for the normal distribution by Shapiro-Wilk's W-test and normalized using the Arc-sin transformation. Differences in pest incidence and total parasitism among study sites were tested by ANOVA followed by Honestly Significant differences (HSD). All analyses were done by using R 3.6.2 (R Core Team 2019).

\section{RESULTS AND DISCUSSION}

\section{The incidence of Erionota thrax and parasitism}

The study recorded $E$. thrax as the BLR in our study area. The incidence of E. thrax at the banana plantation was varied from low to heavy levels. The lowest incidence of BLR was recorded at Maku, Sigi districts, where the banana population is dominated by Kepok cultivar, while the highest incidence was at Kawende, Poso district. The leaf losses due to infested by BLR was vary from only a minor part of the leaf (Figure 2.A) to quite high where most parts of the leaves are defoliated (Figure 2.B). The praimago stages inside the leaf rolls were found at both condition of leaf damages (Figure 2.C-F).
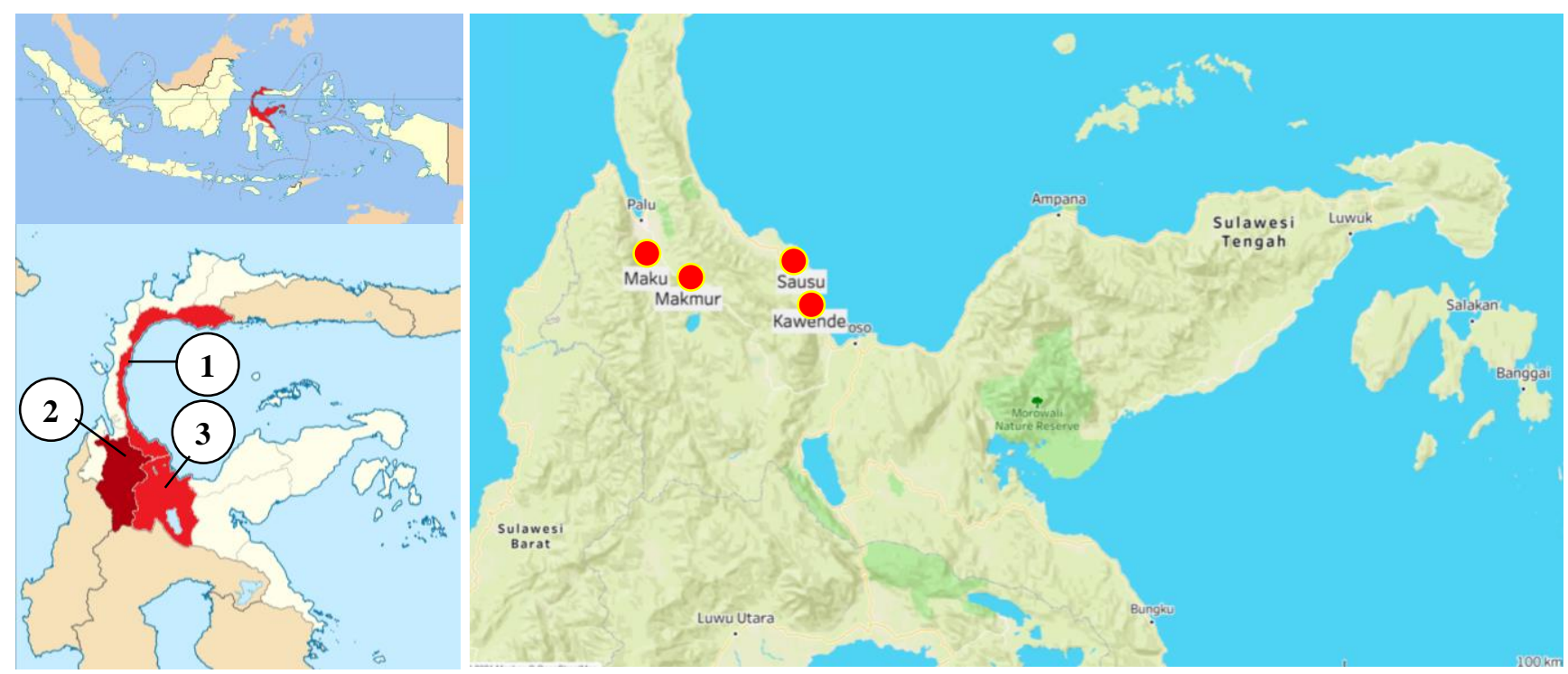

Figure 1. Location of the study sites (indicated by red circles) in Central Sulawesi Province, Indonesia. 1. Parigi Moutong District, 2. Sigi District, 3 Poso District 
Table 1. Description of study sites

\begin{tabular}{lcccc}
\hline \multicolumn{1}{c}{$\begin{array}{c}\text { Environmental } \\
\text { parameters }\end{array}$} & Parigi Moutong District & Sigi District & \multicolumn{2}{c}{ Poso District } \\
\cline { 2 - 5 } & Sausu & Maku & Kawende & Makmur \\
\hline Coordinates & $-1.065816 \mathrm{~S}$, & $-1.0519472 \mathrm{~S}$, & $-1.230886 \mathrm{~S}$, & $-1.137919 \mathrm{~S}$, \\
& $120.526795 \mathrm{E}$ & $119,8880582 \mathrm{E}$ & $120.561421 \mathrm{E}$ & $120.058479 \mathrm{E}$ \\
Altitude $(\mathrm{m}$ asl) & $58 \mathrm{~m}$ & $56 \mathrm{~m}$ & $13 \mathrm{~m}$ & $543 \mathrm{~m}$ \\
Wind Speed $(\mathrm{m} / \mathrm{s})$ & $0.0-1.0$ & $0.1-0.4$ & $0.0-0.6$ & $0.0-0.1$ \\
Temperature $\left({ }^{\circ} \mathrm{C}\right)$ & $31.9-33.8$ & $33.1-35.0$ & $31.2-32.2$ & $32.7-33.4$ \\
Relative humidity $(\%)$ & $60.9-72.3$ & $60.6-63.0$ & $64.5-73.0$ & $58.7-65.0$ \\
Rainfall (mm/year) & 146.21 & 66.44 & 126.32 & 160.38 \\
Banana cultivars & Raja and Mas & Kepok & Raja and Mas & Raja \\
\hline
\end{tabular}

Overall, the BLR incidence at the study sites was in the range of $28.6 \%$ to $85.8 \%$, whereas the total parasitism of the BLR parasitoids also varied among sites, and it was between $15.1 \%$ and $36.4 \%$. BLR incidence was significantly different among sites; $F_{(3,12)}=77.321$, $\mathrm{p}<0.000$ but total parasitism was not; $\mathrm{F}_{(3,12)}=2.010, \mathrm{p}=$ 0.1663 . Interestingly, parasitism levels tended to increase following the incidence of BLR (Figure 3).

\section{Diversity and parasitism of BLR parasitoids}

The study recorded nine species of parasitoids of $E$. thrax. Eight of them belonged to Hymenoptera, i.e., Agiommatus sumatraensis Crawford, 1911; Pediobius erionotae Kerrich,1973; Ooencyrtus pallidipes (Ashmead,1904); Brachymeria lasus (Walker,1814); Brachymeria thracis (Crawford,1911); Cotesia erionatae (Wilkinson,1928); Xanthopimpla gampsura Krieger, 1914, and Casinaria sp., whereas one species i.e., Palexorista solennis (Walker, 1858) is a Diptera (Figure 4).

The parasitoid size was in the range of 1.2 to $14.9 \mathrm{~mm}$ with the bigger size was $X$. gampsura than followed by $B$. lasus and $P$. solennis. The host stage infested by parasitoids was varied, i.e., egg, larva, and pupa of the BLR. They were also different concerning the numbers of immatures per individual host. Three parasitoid species were solitary (one parasitoid per host), and the rest were gregarious (more than one parasitoid per host). The parasitoid B. lasus was the most gregarious parasitoids where the number of adult parasitoids that emerged from one host was about 7 to 15 individuals.

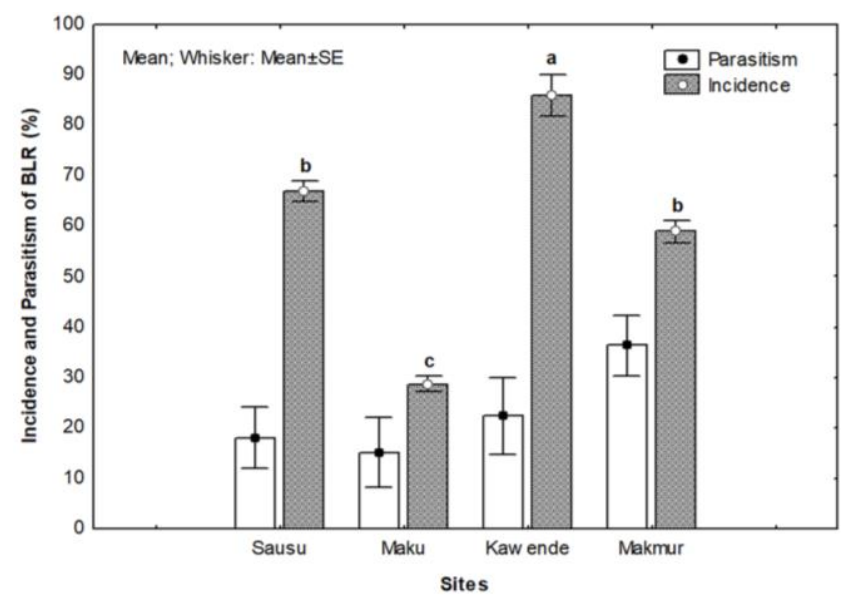

Figure 3. Incidence of banana leaf roller (Erionata thrax) and total parasitism in the study sites. Different letters indicate significant differences (HSD Test, $p<0.01$ )

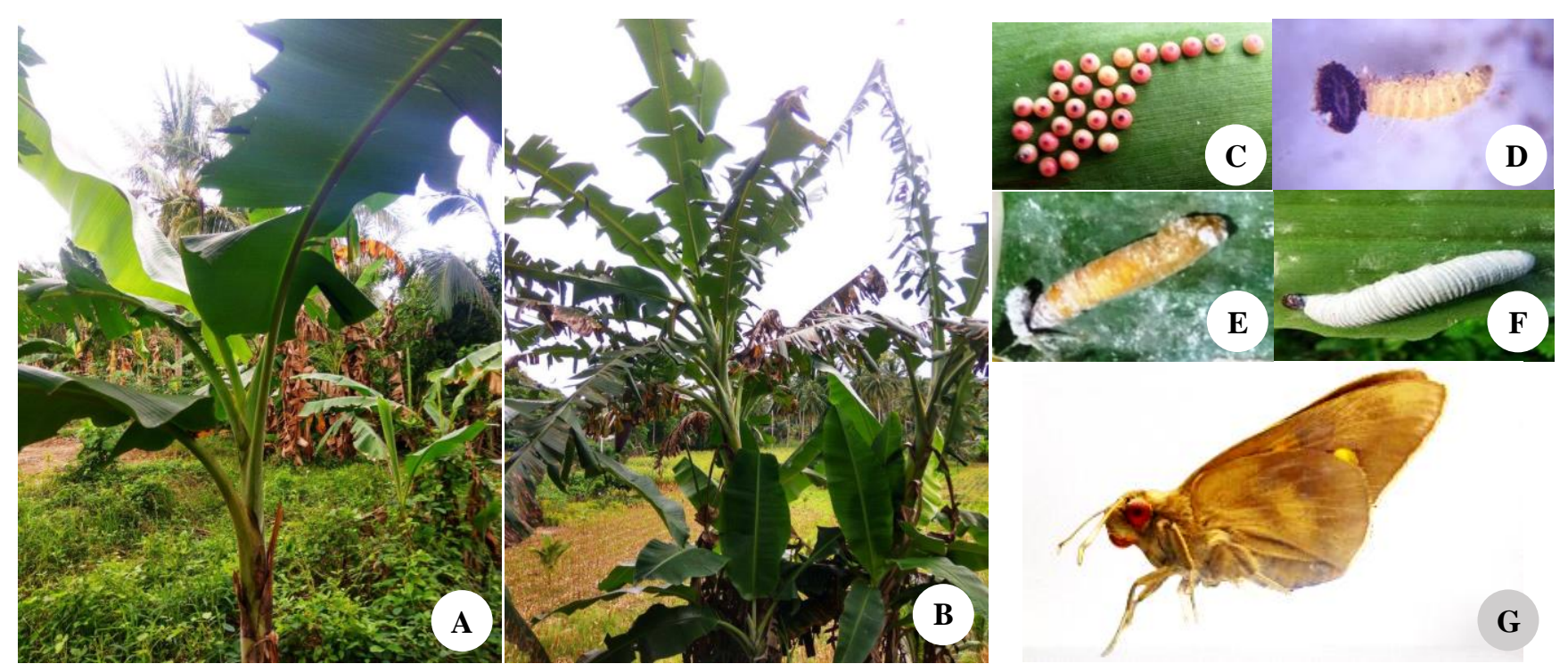

Figure 2. Erionata thrax. A-B. Symptoms of damages on banana; C-G. Life stages of Erionata thrax; C. Eggs; D. Early instar larva; E. Mature larva; F. Pupa; G. Adult 

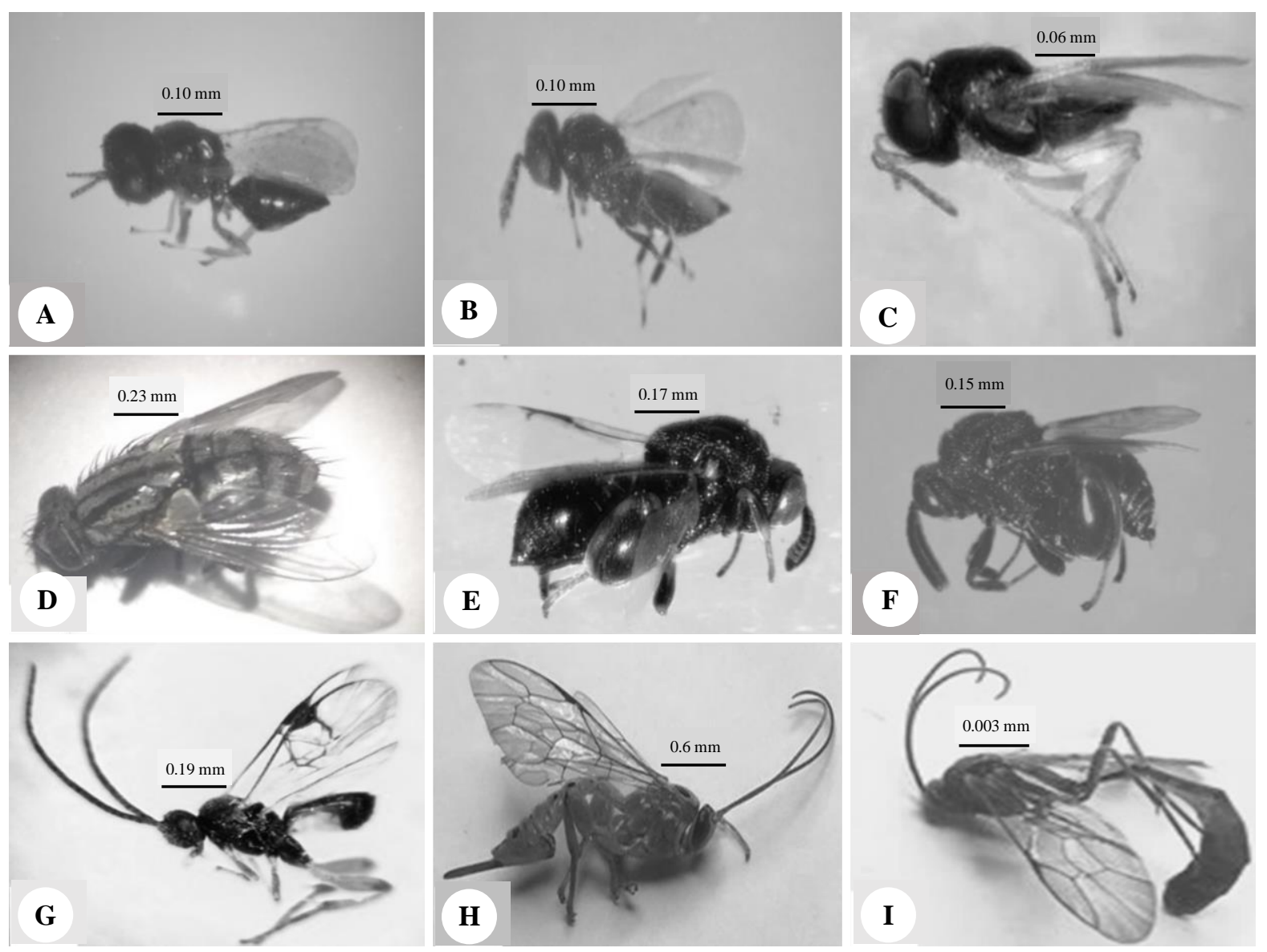

Figure 4. Parasitoids of BLR in Central Sulawesi, Indonesia. A. Agiommatus sumatraensis; B. Pediobius erionotae; C. Ooencyrtus pallidipes; D. Palexorista solennis; E. Brachymeria thracis; F. Brachymeria lasus; G. Cotesia erionatae; H. Xanthopimpla gampsura; I. Casinaria sp.

The number of parasitoids species was different between locations. There were six species found in Maku, five in Kawende, four in Makmur, and two in Sausu. Of nine recorded parasitoids, only B. lasus were distributed in all study sites, while other species were only present at a particular location. The parasitism level of different parasitoid species ranged from 0.0 to $22.1 \%$. The higher parasitism was recorded by B.lasus $(15.9 \pm 2.2 \%)$, followed by $A$. sumatraensis $(9.4 \pm 2.9 \%)$ and $P$. erionotae $(8.8 \pm 2.1 \%)$, while the lowest parasitism was $C$. erionatae and $X$. gampsura $(0.5 \pm 0.1 \%)$ (Table 2$)$.

\section{Discussion}

In this study, we investigated the incidence and parasitism of BLR at different elevates and banana cultivars. Previous studies have been reported the BLR attack on bananas in Indonesia and other tropical countries (Hasyim et al. 1994; Hasyim et al. 1999; Erniwati and Ubaidillah 2011; Irulandi et al. 2018). It is generally known that BLR attacks do not significantly reduce banana production except in high attack rates (Okolle et al. 2006). The population and infestation of this pest are influenced by various abiotic and biotic factors such as elevation, weather, wind, natural enemies, and banana cultivars (Okolle et al. 2010; Irulandi et al. 2018).

For the first time, this study uncovers the incidence of BLR and diversity of its parasitoids at different altitudes and banana cultivars in Central Sulawesi, situated in the Wallacea region known as one of biodiversity hotspots. The study noted that BLR attacked all banana cultivars at the studied sites with a high incidence rate. Interestingly, the lowest incidence was recorded at Maku, Sigi district, where the banana population was dominated by Kepok cultivar. The highest was found at Kawende (Poso District), where three banana cultivars were planted (Raja, Kepok, and Mas). A study conducted in West Java, Indonesia, noted differences in BLR infestation between banana cultivars where Raja cultivar had the highest (Novianti 2008). In India, it has also been reported that BLR preferred a particular banana cultivar, and it might be related to the leaf character, such as the thickness of leaf lamina (Sharanabasappa et al. 2016; Irulandi et al. 2018). It suggests that further investigation might distinguish the resistance of banana cultivars against BLR. 
Table 2. Parasitoids of Erionata thrax, parasitism, and their distributions in the study sites

\begin{tabular}{|c|c|c|c|c|c|c|c|c|}
\hline \multirow{2}{*}{ Ordo/family/species } & \multirow{2}{*}{ Size $(\mathbf{m m})^{1}$} & \multirow{2}{*}{$\begin{array}{c}\text { Host } \\
\text { stadia }\end{array}$} & \multirow{2}{*}{$\begin{array}{c}\text { Type of } \\
\text { parasitoids }\end{array}$} & \multicolumn{4}{|c|}{$\begin{array}{l}\text { Parasitism of each species at a different location }^{2} \\
\text { (Sub-district/District) }\end{array}$} & \multirow{2}{*}{ Average } \\
\hline & & & & $\begin{array}{c}\text { Sausu, } \\
\text { Parimo }\end{array}$ & Maku, Sigi & $\begin{array}{l}\text { Kawende, } \\
\text { Poso }\end{array}$ & $\begin{array}{l}\text { Makmur, } \\
\text { Poso }\end{array}$ & \\
\hline \multicolumn{9}{|l|}{ Hymenoptera/Chalcididae } \\
\hline Brachymeria lasus & $5.4 \pm 0.2$ & Pupa & Gregarious & $13.3 \pm 1.4$ & $17.5 \pm 0.3$ & $11.3 \pm 2.5$ & $21.5 \pm 4.5$ & $15.9 \pm 2.2$ \\
\hline $\begin{array}{l}\text { Brachymeria thracis } \\
\text { Hymenoptera/Braconidae }\end{array}$ & $5.0 \pm 0.3$ & Pupa & Gregarious & $3.3 \pm 1.4$ & 0 & $5.0 \pm 2.5$ & 0 & $2.1 \pm 0.9$ \\
\hline Cotesia erionotae & $3.8 \pm 0.2$ & Larva & Gregarious & 0 & $2.5 \pm 0.5$ & $3.3 \pm 1.4$ & 0 & $0.5 \pm 0.1$ \\
\hline \multicolumn{9}{|c|}{ Hymenoptera/Ichneumodidae } \\
\hline Xanthopimpla gampsura & $14.9 \pm 0.2$ & Pupa & Soliter & 0 & $2.5 \pm 0.5$ & 0 & 0 & $0.5 \pm 0.1$ \\
\hline Casinaria sp. & $1.2 \pm 0.2$ & Larva & Soliter & 0 & 0 & $3.3 \pm 1.4$ & 0 & $0.8 \pm 0.4$ \\
\hline \multicolumn{9}{|l|}{ Hymenoptera/Pteromalidae } \\
\hline Agiommatus sumatraensis & $2.6 \pm 0.3$ & Egg & Soliter & 0 & $22.1 \pm 8.7$ & 0 & $15.3 \pm 3.2$ & $9.4 \pm 2.9$ \\
\hline \multicolumn{9}{|l|}{ Hymenoptera/Eulophidae } \\
\hline Pediobius erionotae & $1.9 \pm 0.5$ & Egg & Soliter & 0 & $15.0 \pm 3.9$ & 0 & $20.0 \pm 4.4$ & $8.8 \pm 2.1$ \\
\hline Hymenoptera/Encyrtidae & & & & & & & & \\
\hline Ooencyrtus pallidippes & $1.5 \pm 0.3$ & Egg & Gregarious & 0 & $3.3 \pm 1.7$ & 0 & $9.0 \pm 1.4$ & $2.3 \pm 0.8$ \\
\hline Diptera: Tachinidae & & & & & & & & \\
\hline Palexorista solennis & $6.9 \pm 0.3$ & Larva & Gregarious & 0 & 0 & $5.0 \pm 2.5$ & 0 & $1.3 \pm 0.6$ \\
\hline
\end{tabular}

Note: ${ }^{1}$ an average size of three individual of imago, ${ }^{2}$ an average of four times observation. Data shown are mean \pm standard error

Due to the insufficient data for statistical analysis, this study did not analyze the significant contribution of environmental factors on BLR incidence. However, the current study detected that the BLR incidence tended to be higher in the banana planted at lower altitudes (Sausu and Kawende). This result was different with Hasyim et al. (1994) reporting that the skipper population is more abundant at a higher elevation. Nevertheless, the results presented in the current study would support the hypothesis that weather parameters, including temperature, moisture, and altitude, together with banana cultivars, might be affecting the incidence of BLR (Kalshoven 1981; Okolle et al. 2010; Sharanabasappa et al. 2016). It is noteworthy that E. thrax may have a favorable condition to establish in banana leaves as long the host is present. Weather conditions may directly influence the larval development or mortality of $E$. thrax or indirectly the fitness of banana as the host plant of E. thrax (Okolle et al. 2010). However, modifying the environmental conditions related to management practices is almost impossible in relation to the cost of spending. Therefore, the presence of parasitoids E. thrax parasitoids is promising for biological control. Parasitoid insects are natural enemies that play an essential role in BLR population control (Hasyim et al. 2003; Okolle et al. 2010). This study found nine species of parasitoids associated with banana skipper pests, which is quite higher than those reported previously in Indonesia (Hasyim et al. 2003; Erniwati and Ubaidillah 2011; Wibowo et al. 2015; Rahmawati et al. 2018). The presence of P. solennis in Central Sulawesi is firstly reported by this study.

The study noted the different levels of parasitism. Of nine parasitoids found, B. lasus was the most distributed species found in all studied sites. This species also had the highest parasitism rate (13.3-21.5\%) and was the most gregarious. Additionally, the size of $B$. lasus was the third larger among recorded parasitoids. All of these characteristics support B. lasus as the enormous potential biological agent of BLR. According to the "adult sizefitness hypothesis" particularly in hymenopteran parasitoids, larger size individuals have several advantages, such as has a high capacity to find high-quality hosts, lifetime fecundity, longevity, and mating success than smaller parasitoids (Gao et al. 2016). The body size positively affects the parasitoids' distances traveled (Fischbein et al. 2018), and these advantages are most likely related to their higher searching efficiency (Iranipour et al. 2020). Furthermore, gregarious parasitoids have several advantages compared with solitary parasitoids (Iranipour et al. 2020; Samkova et al. 2021). For example, Cotesia erionotae (Wilkinson), a gregarious larval parasitoid, has been successfully used to control Erionota spp.in some parts of the world (Kalshoven 1981; Cock 2015).

Other prospective parasitoids for control BLR recorded at the low and high altitudes in this study were $A$. sumatraensis and $P$. erionotae. The parasitism levels were 9.6-21.3\% and 16.7-33.3\%, respectively. The previous study in Central Sulawesi reported about $1.2 \%$ and $3.7 \%$ parasitism for B. lasus and C. erionotae (Rahmawati et al. 2018). Hasyim et al. (1994) recorded a 10-14\% parasitism of eggs by $O$. erionatae and $P$. erionatae, $1-80 \%$ of larvae killed by Casinaria sp., and $50 \%$ of larvae attacked by $C$. erionotae.

Parasitoid, P. solennis that recorded in this study is also potentially to control the BLT. The parasitism level of this parasitoid was quite low. This is in line with Hasyim et al. (1994) and Poorani et al. (2020) highlighted the minor importance of the Tachinid flies (P. solennis). It has been reviewed that parasitizing of the leaf roller caterpillar by Tachinid flies was lower than Hymenoptera flies (O'hara et al. 2009). Nevertheless, Sharanabasappa et al. (2018) encountered two important tachinid parasitoids of E. torus in India. 
Besides reported as the most common and effective biological control agency of banana skippers (Okolle et al. 2010), hymenopteran parasitoids were also important for another group of pests (Wang et al. 2019). However, the effectiveness of parasitoids to manage the banana skipper will increase by combining it with cultural or chemical controls in the scheme of integrated pest management (Okolle et al. 2010; Irulandi et al. 2018). Release the BLR parasitoids could be useful when the BLR population in the fields is low, while chemical control only needs if the population of this pest is high (Okolle et al. 2006).

The present study detected that a higher infestation of E. thrax tended to follow by higher parasitism at all studied sites. This result indicated that parasitoids of BLR performed well in the fields and most likely showed the density-dependent nature of the parasitoids. However, environmental factors such as elevation, rainfall, temperature, and humidity could also be the determining factors directly or indirectly. Differences in topography can result in differences in climate factors and plant phylogeny (Okolle et al. 2010).

It has been reported that incidence of E. torus was positively correlated with maximum temperature and sunshine hours, but negatively correlated with minimum temperature, morning and evening relative humidity and rainfall (Sharanabasappa et al. 2016). High infestation and parasitism of E. thrax usually occur during the rainy season and lower wind speed (Kalshoven 1981; Okolle et al. 2006), but heavy rainfall may roll down the young instar larvae in leaf and wind-torn leaves and interrupt the formation of leaf roll. Meanwhile, the larval period of the BLR was longer during lower temperature and higher humidity (Okolle et al. 2010; Irulandi et al. 2018). This condition might favour their natural enemies such as microbes or parasitoids to develop better.

Future studies would be essential to explore the diversity of the natural enemies of BLR besides parasitoids. Several predators such as a bug, Platynopus melacanthus, birds (particularly crows), ants, and spiders contributes to the mortality of the pra-imago of E. thrax (Okolle et al. 2010; Poorani et al. 2020). Another challenge is to explore the BLR-parasitoid association by using a DNA barcoding approach to cope with the problem of the identification due to the incompleteness collection of the BLR specimens (Cock et al. 2019).

In conclusion, this study provides insight into the current situation of BLR incidence in Central Sulawesi, Indonesia. BLR infestation is a major problem with incidence rich up to $85 \%$. This pest incidence tended to be higher at a higher altitude. However, Kepok cultivar seemed to be less prone to BLR infestation compared with Raja and Mas cultivars. In addition, this study also recorded nine species of parasitoids for the pest E. thrax. These included eight species of insects in the wasp order and one in the fly order. They were A. sumatraensis, $P$. erionataea, O. pallidipes, B. lasus, B. thracis, C. erionatae, $X$. gampsura, $P$. solennis, and Casinaria sp. Parasitoid $B$. lasus was the most potential for controlling $E$. thrax followed by $A$. sumatraensis, and $P$. erionotae.

\section{ACKNOWLEDGEMENTS}

This research was financially supported by the professor's research and scientific publication program of the Tadulako University of Indonesia in 2019. We thank taxonomists of MZB of the National Research and Innovation Agency (BRIN), particularly Prof. Rosichon Ubaidillah, for the parasitoid identification and Dicky Wahyudi for collecting of the banana skipper.

\section{REFERENCES}

Abdul JK, Gosh SM. 2020. Biology and damage of banana skipper Erionota torus (Evans) from Malabar region of Kerala. Indian J Entomol 82 (3): 429-434. DOI: 10.5958/0974-8172.2020.00112.1.

Cock MJW. 2015. A critical review of the literature on the pest Erionota spp. (Lepidoptera, Hesperiidae): Taxonomy, distribution, food plants, early stages, natural enemies and biological control. CAB rev 10 (7): 1-30. DOI: 10.1079/PAVSNNR201510007.

Cock MJW, Buddie AG, Cafa G. 2019. Piloting the use of DNA barcoding in support of natural enemy surveys: New parasitoid records for banana skippers (Erionota spp., Lepidoptera, Hesperiidae) in Malaysia. J Asia Pac Entomol 22: 183-188. DOI: 10.1016/j.aspen.2018.12.019.

Ditlin Horti, Direktorat Perlindungan Hortikultura. 2019. Statistik Iklim, OPT dan DPI. Pusat Data dan Informasi Pertanian. http://ditlin.hortikultura.pertanian.go.id.

Erniwati, Ubaidillah R. 2011. Hymenopteran parasitoids associated with the banana-skipper Erionata thrax L. (Insecta: Lepidoptera, Hesperiidae) in Java, Indonesia. Biodiversitas 12 (2): 76-85. DOI: 10.13057/biodiv/d120204

Fischbein D, Villacide JM, De La Vega G, Corley JC. 2018. Sex, life history and morphology drive individual variation in flight performance of an insect parasitoid. Ecol Entomol 43: 60-68. DOI: 10.1111/een.12469.

Gao S, Tang Y, Wei K, Wang X, Yang Z, Zhang Y. 2016. Relationships between body size and parasitic fitness and off spring performance of Sclerodermus pupariae Yang et Yao (Hymenoptera: Bethylidae). Plos One 11 (7): e0156831. DOI: 10.1371/journal.pone.015683.

Goulet H, Huber JT. 1993. Hymenoptera of the World: An Identification Guide to Families. Canada Communication Group, Ottawa, Canada.

Hasyim A, Hasan N, Syafril, Harlion, Nakamura K. 1994. Parasitoids of the banana skipper Erionota thrax (L.) in Sumatera Barat, Indonesia, with notes on their life history, distribution and abundance. Tropics 3 (2): 131-142. DOI: 10.3759/tropics.3.131.

Hasyim A, Hasan N, Syafril, Harlion, Nakamura K. 1999. Detection of egg parasitism and its mortality on the banana skipper, Erionota thrax (L.) eggs in the province of West Sumatera (Indonesia). Jurnal Hortikultura 8 (4): 1278-1283.

Hasyim A, Kamisar, Nakamura K. 2003. Mortalitas stadia pradewasa hama penggulung daun pisang Erionota thrax (L) yang disebabkan oleh parasitoid. Jurnal Hortikultura 13 (2): 114-119. DOI: 10.21082/jhort.v13n2.2003.p114-119. [Indonesian]

Iranipour S, Ahmadpour S, Asgari S. 2020. Gregarious development alters host utilization by the egg parasitoid Ooencyrtus fecundus (Hymenoptera: Encyrtidae). J Crop Prot 9 (3): 523-535.

Irulandi S, Manivannan MI, Kumar AR. 2018. Bio-ecology and management of the banana skipper, Erionota thrax L. (Hesperiidae: Lepidoptera). J Entomol Zool Stud 6 (2): 262-265.

Kalshoven LGE. 1981. The Pest of Crop in Indonesia. Ichtiar Baru van Houve, Jakarta.

Novianti F. 2018. Hama Penggulung Daun Pisang Erionata thrax Linnaeus (Lepidoptera: Hesperidae) dan Musuh Alaminya di TempatTempat dengan Ketinggian Berbeda. [Thesis]. Institut Pertanian Bogor, Bogor. [Indonesian].

O'hara JE, Shima H, Zhang C. 2009. Annotated catalogue of the Tachinidae (Insecta: Diptera) of China. Zootaxa 2190: 1-236. DOI: 10.11646/zootaxa.2190.1.1

Okolle NJ, Mansor M, Ahamd A. 2006. Seasonal abundance of banana skipper, Erionata thrax (Lepidoptera: Hesperiidae) and its parasitoids in a commercial plantation and a subsistence farm in Penang, 
Malaysia. Intl J Trop Insect Sci 26 (3): 197-206. DOI: 10.1079/IJT2006116.

Okolle NJ, Abu AA, Mashhor M. 2010. Bioecology and management of banana skipper (Erionota thrax). Tree For Sci Biotech 4 (1): 22-31.

Pratiwi IY, Supriyadi, Sholahuddin. 2020. Hubungan antara penyobekan daun secara mekanik terhadap serangan penggulung daun pisang. Agrosains: Jurnal Penelitian Agronomi 22(1): 7-11. DOI: 10.20961/agsjpa.v22i1.29834. [Indonesian].

Poorani J, Padmanaban B, Deshmukh S, Thanigairaj R, Ragesh G. 2020 A review of the pest status and natural enemy complex of banana skipper Erionota torus Evans in South India and its management. Indian J Entomol 82 (3): 479-492. DOI: 10.5958/09748172.2020.00123.6.

Rahmawati, Pasaru F, Yunus M. 2018. Observasi jenis parasitoid larva penggulung daun pisang Erionata thrax Linnaeus (Lepidoptera: Hesperidae) pada ketinggian tempat yang berbeda di Kabupaten Sigi. Agrotekbis 6 (2): 239-246.

R Core Team. 2019. R: A Language and Environment for Statistical Computing. $\mathrm{R}$ Foundation for Statistical Computing, Vienna. https://www.R-project.org.

Samková A, Raška J, Hadrava J, Skuhrovec J. 2021. A novel twogeneration approach for understanding the population dynamics of gregarious parasitoids. bioRxiv 1-14. DOI: 10.1101/2021.02.22.432341
Sharanabasappa, Kalleshwaraswamy CM, Adivappar N, Lavanya MN 2016. Population dynamics and natural enemies of Erionota torus Evans (Lepidoptera: Hesperiidae) on two cultivars of banana in Karnataka. Pest Manag Horticult Ecosyst 22 (1): 34-39.

Sharanabasappa, Kalleshwaraswamy CM, Maruthi MS, Shima H. 2018. Population dynamics and new record of larval parasitoids, Senometopia sp. and Winthemia sumatrensis (Townsend) (Diptera: Tachinidae) on banana skipper, Erionota torus Evans (Lepidoptera: Hesperiidae) from South Karnataka. J Biol Control 32 (1): 48-51. DOI: $10.18311 / \mathrm{jbc} / 2018 / 18744$.

Suyamto I, Djatnika, Sutanto A. 2005. Banana R\&D in Indonesia: Updates and highlights. Proceedings of the 3rd BAPNET Steering Committee. Guangzhou, China, 23-26 November 2004.

Wang Z, Liu Y, Shi M, Huang J, Chen X. 2019. Parasitoid wasps as effective biological control agents. J Integr Agric 18 (4): 705-715. DOI: $10.1016 / \mathrm{S} 2095-3119(18) 62078-7$.

Wibowo L, Indriyati, Purnomo. 2015. The abundance and diversity of the parasitoid of banana leaf skipper pest (Erionota thrax L.) in South Lampung Regency. Jurnal HPT Tropika 15 (1): 26-32. DOI: 10.23960/j.hptt.11526-32. [Indonesian].

Zhang Y, Li W, Huang D. 2005. A taxonomic study of Chinese species of Ooencyrtus (Insecta: Hymenoptera: Encyrtidae). Zool Stud 44: 347360. 